\title{
A HISTOPATHOLOGICAL REVIEW OF SPLENECTOMIES IN HEMATOLOGICAL DISORDERS IN PAEDIATRIC AGE.
}

M. Ramani ${ }^{1}$, D. Ranganath², Kazi Wajid Husain³, K. Ramesh Reddy4, Sai Yasaswini' ${ }^{5}$ Puja Deshmukh6.

\section{HOW TO CITE THIS ARTICLE:}

M. Ramani, D. Ranganath, Kazi Wajid Husain, K. Ramesh Reddy, Sai Yasaswini, Puja Deshmukh. "A histopathological review of splenectomies in hematological disorders in paediatric age." Journal of Evolution of Medical and Dental Sciences 2013; Vol2, Issue 28, July 15; Page: 5088-5099.

ABSTRACT: - BACKGROUND: The spleen was considered by Galen as "an organ of mystery," by Aristotle as unnecessary, by Pliny as an organ that might hinder the speed of runners and also as an organ that produced laughter and mirth, a notion reaffirmed in the Babylonian Talmud. Splenectomy as a therapeutic modality is widely used in management of hematological disorders. Splenectomy is specifically indicated for children with Thalassemia, Hereditary spherocytosis and Chronic Idiopathic thrombocytopenic purpura refractory to medical treatment considering its advantages of being an effective procedure. AIMS AND OBJECTIVES: The objectives of the present study was to determine various indications, age and sex incidence for splenectomies in hematological diseases and to study the histopathological changes of the splenectomy specimens in detail. MATERIAL AND METHODS: The present retrospective study was undertaken at Department of Pathology, Paediatric Referral Hospital. We reviewed 17 specimens that were received over a span of 5 years. Routine hematological, biochemical, serological laboratory investigations and bone marrow aspirates were evaluated. The splenectomy specimens were examined after routine processing and staining with Haematoxylin and Eosin. RESULTS: The most common indication for splenectomy was Thalassemia (41.1\%). Splenectomy was commonly done in the age group 18 months - 12 years. The incidence of splenectomy was 1.8 times more common in boys than in girls. Histopathological picture of spleen in various lesions was consistent with the changes secondary to the disease. CONCLUSION: Thalassemia proved to be the most common indication for splenectomy in paediatric age group followed by hereditary spherocytosis and refractory Idiopathic thrombocytopenic purpura. Splenectomy has been the safest and most effective procedure for children with Chronic or Refractory Idiopathic thrombocytopenic purpura. Rarely splenectomy has shown to be beneficial in patients with lymphoma, Kasabach-Merritt syndrome and Gaucher's disease.

KEYWORDS: Splenectomy, Thalassemia, Hereditary spherocytosis, Idiopathic thrombocytopenic purpura, Lymphoma, Kasabach-Merritt syndrome, Gaucher's disease.

INTRODUCTION: Spleen plays a vital role in defending our body against infections by producing specific antibodies and filtering out encapsulated organisms. Splenectomy as a therapeutic modality is widely used in management of hematological disorders [1].

The spleen was considered by Galen as a mysterious organ. Aristotle concluded that spleen was not essential for life [2]. Pliny felt it as an organ that might hinder the speed of runners and also as an organ that produced laughter and mirth, a notion reaffirmed in the Babylonian Talmud [3].

Spleen is frequently involved in variety of pathological conditions in infants and children. These pathological conditions affect spleen either primarily or involve spleen as a part of systemic disease. 


\section{ORIGINAL ARTICLE}

Splenomegaly in children is usually first detected on physical examination. Palpable spleen may be normal or pathological. It is not surprising to find about one third of new-borns and $10 \%$ of children normally having a palpable spleen. On physical examination the tip of the normal, palpable spleen is soft in consistency, smooth, non-tender and remains less than 1-2 cm below the left costal margin.

A spleen that is pathologically enlarged is often has a firm consistency with an abnormal surface, the tip of the spleen is enlarged more than $1-2 \mathrm{~cm}$ below the costal margin and is commonly related with signs and symptoms of the underlying disease. It is meaningful to consider further evaluation when these features are present [4].

Splenectomy plays a very important role in children with thalassemia, hereditary spherocytosis and chronic Idiopathic thrombocytopenic purpura recalcitrant to medical treatment. The transfusion requirements are reduced and its attendant adverse risks mainly iron overload, eliminates discomfort from mechanical pressure of enlarged spleen, avoids risks of acute splenic sequestration crisis, and helps in managing splenic abscess. It relieves patient from cytopenias due to hypersplenism and Idiopathic mediated destruction of platelets in the spleen.

Currently common indications for splenectomise in children are hereditary spherocytosis, Idiopathic Thrombocytopenic Purpura intractable to medication [5] and others like Thalassemia with splenomegaly and metabolic disorders.

In this present study, we attempt to define various indications, age and sex incidence for splenectomies in hematological diseases and to review the histopathological changes of the splenectomy specimens in detail.

MATERIAL AND METHODS: The Present study was undertaken for a period of 5 years from August 2003 to July 2008 at Department of Pathology, Paediatric referral Hospital. A total of 17 cases were studied. Laboratory workup included haemoglobin estimation, complete blood picture, routine biochemical and serological tests and complete urine examination.

Bone marrow aspiration was performed in the cases of Idiopathic thrombocytopenic purpura, while haemoglobin electrophoresis and osmotic fragility were performed in haemolytic anaemia and enzyme assay in Gaucher's disease were done. Splenectomy specimens were formalin fixed, paraffin embedded and sectioned. The slides were stained with Haematoxylin and Eosin.

RESULTS: A total of 17 children were included in our study. We had 10 male children and 7 females. According to this present study, the most common indication for paediatric splenectomy was Thalassemia with $41 \%$ of the cases (7/17).It was followed by hereditary spherocytosis with $29.4 \%$ (5/17) and refractory Idiopathic Thrombocytopenic Purpura having 11\% (2/17) of the cases. Less common indications were Kasabach Merritt syndrome, lymphoma and Gaucher's disease, one each comprising of $5.8 \%$ of cases (Table 1 ).

THALASSEMIA: All the cases of thalassemia were boys between the age ranges of 5-12 years. About $28 \%$ of cases presented with $\mathrm{Hb} \%$ less than $5 \mathrm{~g} / \mathrm{dl}$ and $72 \%$ with $\mathrm{Hb} \%$ less than $10 \mathrm{~g} / \mathrm{dl}$. In all cases Red blood cell (RBC) morphology showed anisopoikilocytosis, polychromasia, target cells, fragmented RBC, microcytic/hypochromic blood picture, and nucleated RBC ranging from 2 to 16 /100 WBC(Table 2). One case showed low platelet count. Osmotic fragility was decreased in all 


\section{ORIGINAL ARTICLE}

cases. Haemoglobin electrophoresis was abnormal with elevated HBF and HBA2.There was splenomegaly, massive in 43\%, moderate in 53\% and mild in rest of cases. Spleen was large and firm in most cases ranging from 750-1000 grams, cut section was dark red with prominent red pulp (Figure 1A). Microscopy showed prominent red pulp, distended congested cords of Billroth full of RBCs; sinuses were relatively empty, compressed. Hemosiderin deposition present and hyperplastic white pulp with reactive follicular hyperplasia. Gamna gandy were bodies seen in red pulp (Figure 1B).

HEREDITARY SPHEROCYTOSIS: Hereditary spherocytosis was seen in $29.4 \%$ of cases ( 5 /17 ) (Table 3) between the age groups of 11-12 years and male to female ratio was $4: 1$ clearly showing male preponderance. All the patients presented with pallor and jaundice. $\mathrm{Hb} \%$ of most patients was in range of 6-10 g/dl except for one showing $5 \mathrm{~g} / \mathrm{dl}$. Peripheral smear showed plenty of spherocytes and polychromasia (Figure 7A).40\% cases showed associated cholecystitis for which cholecystectomy was done. Osmotic Fragility Test showed increased fragility of RBC in all cases. Haemoglobin electrophoresis was normal in all. All cases showed moderate enlargement of spleen (Figure 2A), decreased white pulp. Cords were filled with spherocytes; sinuses empty (Figure 2B). Macrophages and iron accumulation in cords with fibrosis seen.

IDIOPATHIC THROMBOCYTOPENIC PURPURA: Idiopathic thrombocytopenic purpura was seen in $11.7 \%$ of cases $(2 / 17)$. Both the cases were boys, with age group between 8-11 years and with platelet counts less than 10000/cumm (Table 4). Bone marrow smears showed increase in megakaryocytes (Figure 7B). Spleen showed mild enlargement (Figure 3A) with reactive follicular hyperplasia in white pulp. Red pulp was prominent, with increased histiocytes, platelets and debris (Figure 3B).

GAUCHER'S DISEASE: In our study we had an isolated case of gaucher's disease aged $1 \frac{1}{2}$ year old and was a female child, Spleen was moderately enlarged, Cut section showed pale areas in spleen (Figure 4A). Microscopically, Spleen showed nodular \& diffuse infiltrates of "Gaucher cells" in red pulp and these were PAS positive. (Figure 4B).

KASABACH MERRITT SYNDROME: A lone case of Kasabach Merritt syndrome was encountered in our series. The child was a 7 year old girl with a massive enlargement of spleen, Cut section gray tan and congested (Figure 5A). Microscopy showed proliferation of vascular channels of variable size lined by single layered endothelium (Figure 5B)

LYMPHOMA: We also encountered an 8 year female child with B cell lymphoma. Spleen was moderately enlarged, on cut section showing well-defined grey white mass, surrounded by normal appearing(Figure 6A). Histopathology of spleen showed monotonous infiltrate of atypical lymphocytes with scant cytoplasm, large nuclei and open chromatin (Figure 6B).

DISCUSSION: Splenectomies have been done as early as 2,000 years ago, according to the vague references noted in ancient Greek and Roman literature [6]. The first recorded splenectomy was 


\section{ORIGINAL ARTICLE}

performed for splenomegaly in 1549 by Adrian Zaccarello. In 1678, Nicholas Mathias was credited with first total splenectomy for trauma [7].

In a retrospective study done by Mayo (1928) in about 500 splenectomies done principally for anemia and leukaemia establish that $80 \%$ of patients had excellent results and lived comfortably [7].

In a study by Esposito et al. (1998) [8] included 19 children that underwent laparoscopic splenectomy. Their ages ranged between 4 and 14 years. The study comprised 14 girls and 5 boys, showing female preponderance. In a study undertaken by Durakbasa et al. (2006) [1] showed female preponderance. Krishna et al. (1987) [9] reviewed 13 patients with hematological disorders, of whom 12 were male children and one female, showing male preponderance. Our study reported male preponderance similar to the findings of Krishna et al. (1987).

According to Krishna et al. (1987) [9] the commonest indication of splenectomy was Thalassemias, followed by idiopathic thrombocytopenic purpura. While in the study by Minke et al. (2000) [10]the most common indication for splenectomy was Idiopathic Thrombocytopenic Purpura followed by Thalassemia. Machado et al. (2009) [11] And Al-Salem et al. (1996) [12] reported Sickle Cell Disease as the most common indication for splenectomy followed by Thalassemia (Table 5).

Esposito et al. (1998) [8] reported hereditary spherocytosis to be the commonest indication of splenectomy followed by $\beta$-thalassemia and idiopathic thrombocytopenia purpura. Hereditary spherocytosis was most common indication in a study by Durakbasa et al. (2006)[1].

Our study showed Thalassemias as the most common indication for splenectomy in paediatric age group as reported by Krishnaet al. (1987) ${ }^{[9]}$ (Table 5).

Spleen can be very large in $\beta$-Thalassemia and hereditary spherocytosis. Whereas in idiopathic thrombocytopenic purpura, the spleen is only slightly enlarged. Esposito et al. (1998) [8] reported in their series regarding the size in 19 children after laparoscopic splenectomy. Spleen was markedly enlarged in cases of hereditary spherocytosis weighing between 500-1400 grams followed by $\beta$-thalassemia weighing between 400-620 grams. While spleen in idiopathic thrombocytopenic purpura was mildly enlarged and weighed in the range of 175-340 grams.

In this present study gross enlargement of spleen was observed in $88.2 \%$ of cases. The cases of Thalassemias showed massive enlargement weighing around 750-1000 grams. Spleen was moderately enlarged in hereditary spherocytosis, while mildly enlarged in cases of Idiopathic thrombocytopenic purpura. Our results are consistent with that of the findings reported by Esposito et al. (1998) [8].

Approximately 95\% of the patients in gaucher's disease present with enlarged spleen. A prominent feature of gaucher's disease is hypersplenism which leads to severe bleeding with anemia. Although recurrence is a rule, splenectomy corrects these abnormalities [13].Ein et al. (1977) [14] reported 2 cases of gaucher's disease in over 182 paediatric patients they reviewed. Our study reported an isolated case of gaucher's disease in the spleen.

Kasabach \&Merritt (1940) described the association of thrombocytopenic purpura with the occurrence of a rapidly enlarging capillary haemangioma in a new-born male baby. KasabachMerritt syndrome which includes anaemia, thrombocytopenia and coagulopathy have been reported with large hemangiomas[15].

Georgina W. Hall (2001) [16]reviewed two cases of Kasabach-Merritt syndrome involving spleen. The first case was a six month old female presenting with auto Idiopathic haemolytic 


\section{ORIGINAL ARTICLE}

anaemia and thrombocytopenia. On histopathology the spleen showed multiple hemangiomata. The second case was thirteen month old male presenting with bruising and hepatosplenomegaly. On histopathology spleen showed multiple hemangiomata.

Musser et al. (1984)[6] reported hereditary spherocytosis (48\%) as the most common indication of splenectomy followed by Idiopathic Thrombocytopenic Purpura (17\%) and Hodgkin's disease (13\%).Our study showed an isolated case of splenic B cell lymphoma (Non-Hodgkin's lymphoma).

CONCLUSION: Thalassemia proved to be the most common indication for splenectomy in paediatric age group followed by hereditary spherocytosis and refractory Idiopathic Thrombocytopenic Purpura. Total splenectomy in children with Thalassemia has shown decreased requirements of blood transfusions thereby improving the quality of life. Splenectomy has been the safest and most effective procedure for children with chronic or refractory Idiopathic Thrombocytopenic Purpura and should be considered when medical management fails or causes excessive toxicity. The responses to splenectomy are usually long-lasting. Partial splenectomy for Hereditary spherocytosis has reversed anemia sparing the essential functions of spleen. Rarely splenectomy has shown to be beneficial in patients with lymphoma, Kasabach Merritt syndrome and Gaucher's disease.

\section{REFERENCES}

1. Durakbasa CU, Timur C, Sehiralti V, Mutus M, Tosyali N, Yoruk A. Pediatric splenectomy for hematological diseases: outcome analysis. Pediatr Surg Int. 2006 Aug; 22(8):635-9.

2. Al-Salem AH. The role of splenectomy in patients with sickle cell disease. AnnSaudi Med. 1997 May; 17(3):316-20.

3. M.M. Porecha, D. Udani, V. Mehta, A. Gami: Splenectomy in Management of Thalassemia Major - A Boon for the Little Angel. The Internet Journal of Surgery. 2010 Volume 24 Number 1.

4. A. Gozman "Pediatric Splenomegaly." Medscape. Updated: Mar 7, 2013. Web. 2.40 p.m. on 15April. 2013, http://emedicine.medscape.com/article/958739

5. Al-Salem AH, Nasserulla Z. Splenectomy for children with thalassemia. Int Surg. 2002 OctDec; 87(4):269-73.

6. Musser G, Lazar G, Hocking W, Busuttil RW. Splenectomy for hematologic disease. The UCLA experience with 306 patients. Ann Surg. 1984 Jul; 200(1):40-5.

7. F.Q. Parray, N.A. Wani, K.A. Wani, M.A. Wani, R.A. Wani: Some Unusual Indications of Splenectomy. The Internet Journal of Surgery. 2006 Volume 7 Number 2.

8. Esposito C, Corcione F, Ascione G, Garipoli V, Di Pietto F, De Pasquale M. Splenectomy in childhood. The laparoscopic approach. Surg Endosc. 1998Dec; 12(12):1445-8.

9. Krishna A, Bhatnagar V, Arya LS, Mitra DK. Splenectomy for hematological disorders. Indian J Pediatr. 1987 May-Jun; 54(3):409-13.

10. Minkes RK, Lagzdins M, Langer JC. Laparoscopic versus open splenectomy in children. J Pediatr Surg. 2000 May; 35(5):699-701.

11. Machado NO, Grant CS, Alkindi S, Daar S, Al-Kindy N, Al Lamki Z, Ganguly SS. Splenectomy for haematological disorders: a single center study in 150 patients from Oman. Int J Surg. 2009 Oct; 7(5):476-81. 
12. Al-Salem AH, Qaisaruddin S, Nasserallah Z, Al-Dabbous I, Al-Jam'a A. Splenectomy in patients with sickle-cell disease. Am J Surg. 1996 Sep; 172(3):254-8.

13. Guggenbuhl P, Grosbois B, Chalès G. Gaucher disease. Joint Bone Spine. 2008 Mar; 75(2):11624.

14. Ein SH, Shandling B, Simpson JS, Stephens CA, Bandi SK, Biggar WD, Freedman MH. The morbidity and mortality of splenectomy in childhood. Ann Surg. 1977 Mar; 18 5(3):307-10.

15. Freeman JL, Jafri SZ, Roberts JL, Mezwa DG, Shirkhoda A. CT of congenital and acquired abnormalities of the spleen. Radiographics. 1993 May; 13(3):597-610.

16. Hall GW. Kasabach-Merritt syndrome: pathogenesis and management. Br J Haematol. 2001 Mar; 112(4):851-62.

TABLE 1: The indications of splenectomy in various hematological diseases.

\begin{tabular}{|l|l|l|l|}
\hline Sl. No & HEMATOLOGICAL DISORDER & NO. OF CASES (17) & \% OF INCIDENCE \\
\hline 1 & Thalassemia & 7 & 41.1 \\
\hline 2 & Hereditary spherocytosis & 5 & 29.4 \\
\hline 3 & Idiopathic thrombocytopenic purpura & 2 & 11.7 \\
\hline 4 & Lymphoma & 1 & 5.8 \\
\hline 5 & Kasabach Merritt syndrome & 1 & 5.8 \\
\hline 6 & Gaucher's disease & 1 & 5.8 \\
\hline
\end{tabular}


TABLE 2: The hematological findings in patients with Thalassemia.

\begin{tabular}{|c|c|c|c|c|c|c|}
\hline $\begin{array}{l}\text { SL. } \\
\text { NO }\end{array}$ & $\begin{array}{l}\text { AGE } \\
\text { (YEARS) }\end{array}$ & SEX & $\mathbf{H b} \%$ & TC(CMM) & $\begin{array}{l}\text { PLATEL } \\
\text { ET } \\
\text { COUNT }\end{array}$ & RBC MORPHOLOGY \\
\hline 1 & 5 & Male & 4.6 & 6300 & 50000 & $\begin{array}{l}\text { Anisocytosis, polychromasia, targets, fragmented } \\
\text { RBC, hypersegmented polymorphs, } N R B C=2 / 100 \\
\text { WBC , microcytes + }\end{array}$ \\
\hline 2 & 10 & Male & 4.8 & 14000 & 2.4 lakhs & $\begin{array}{l}\text { Anisocytosis, polychromasia, targets, fragmented } \\
\text { RBC, hypersegmented polymorphs, NRBC=5-6/100 } \\
\text { WBC , microcytes + }\end{array}$ \\
\hline 3 & 12 & Male & 7.1 & 9200 & 1.2 lakhs & $\begin{array}{l}\text { Anisocytosis, polychromasia, targets, fragmented } \\
\text { RBC, hypersegmented polymorphs, NRBC=3-4/100 } \\
\text { WBC, microcytes + }\end{array}$ \\
\hline 4 & 10 & Male & 7.5 & 8600 & 1.6 lakhs & $\begin{array}{l}\text { Anisocytosis, polychromasia, targets, fragmented } \\
\text { RBC, hypersegmented polymorphs, NRBC }=2-4 / 100 \\
\text { WBC , microcytes + }\end{array}$ \\
\hline 5 & 7 & Male & 8.1 & 10000 & 1.2 lakhs & $\begin{array}{l}\text { Anisocytosis, polychromasia, targets, fragmented } \\
\text { RBC, hypersegmented polymorphs, NRBC }=1-2 / 100 \\
\text { WBC ,microcytes }+ \text {, hypochromic }\end{array}$ \\
\hline 6 & 12 & Male & 9.8 & 8500 & 2.4 lakhs & $\begin{array}{l}\text { Anisocytosis, polychromasia, targets, fragmented } \\
\text { RBC, hypersegmented polymorphs, NRBC }=1-2 / 100 \\
\text { WBC , microcytes + }\end{array}$ \\
\hline 7 & 8 & Male & 8.6 & 9600 & 2.5 lakhs & $\begin{array}{l}\text { Anisocytosis, polychromasia, targets, fragmented } \\
\text { RBC, hypersegmented polymorphs, NRBC }=1-2 / 100 \\
\text { WBC, microcytes + }\end{array}$ \\
\hline
\end{tabular}

TABLE 3: The hematological findings in patients with hereditary spherocytosis.

\begin{tabular}{|l|l|l|l|l|l|l|}
\hline SL.NO & $\begin{array}{l}\text { AGE } \\
\text { (YEARS) }\end{array}$ & SEX & Hb\% & TC(CMM) & $\begin{array}{l}\text { PLATELET } \\
\text { COUNT(LAKHS) }\end{array}$ & RBC MORPHOLOGY \\
\hline 1 & 11 & Female & 5 & 8000 & 2.1 & $\begin{array}{l}\text { Spherocytes } \\
\text { polychromasia }\end{array}$ \\
\hline 2 & 11 & Female & 6.2 & 7200 & 1.6 & $\begin{array}{l}\text { Spherocytes } \\
\text { polychromasia }\end{array}$ \\
\hline 3 & 12 & Female & 8 & 10400 & 2.4 & $\begin{array}{l}\text { Spherocytes } \\
\text { polychromasia }+\end{array}+$ \\
\hline 4 & 11 & Female & 8.4 & 8600 & 1.8 & $\begin{array}{l}\text { Spherocytes } \\
\text { polychromasia }\end{array}+$ \\
\hline 5 & 11 & Male & 10 & 9700 & 2.4 & $\begin{array}{l}\text { Spherocytes } \\
\text { polychromasia }\end{array}$ \\
\hline
\end{tabular}




\section{ORIGINAL ARTICLE}

TABLE 4: The hematological findings in patients with idiopathic thrombocytopenic purpura.

\begin{tabular}{|l|l|l|l|l|l|l|}
\hline SL.NO & $\begin{array}{l}\text { AGE } \\
\text { (YEARS) }\end{array}$ & SEX & Hb\% & $\begin{array}{l}\text { TC } \\
\text { (CMM) }\end{array}$ & $\begin{array}{l}\text { PLATELETS } \\
\text { COUNT }\end{array}$ & BONE MARROW ASPIRATE FINDINGS \\
\hline 1 & 11 & Male & 14.8 & 7500 & $<10,000$ & $\begin{array}{l}\text { Increased megakaryocytes (both } \\
\text { mature and immature) }\end{array}$ \\
\hline 2 & 8 & Male & 11.2 & 8000 & $<10,000$ & $\begin{array}{l}\text { Increased megakaryocytes (both } \\
\text { mature and immature) }\end{array}$ \\
\hline
\end{tabular}

TABLE 5: The comparison of the present study with available literature.

\begin{tabular}{|l|l|l|l|l|l|l|}
\hline SL.NO & INDICATION & $\begin{array}{l}\text { KRISHNA [9] } \\
\text { et al. (\%) }\end{array}$ & $\begin{array}{l}\text { MINKE [10] } \\
\text { et al (\%) }\end{array}$ & $\begin{array}{l}\text { MACHADO [11] } \\
\text { et al (\%) }\end{array}$ & $\begin{array}{l}\text { AL SALEM } \\
\text { [12] et al } \\
\text { a\%) }\end{array}$ & $\begin{array}{l}\text { PRESENT } \\
\text { STUDY } \\
\text { (\%) }\end{array}$ \\
\hline 1. & Thalassemia & 46.2 & 17.4 & 22.6 & 20.9 & 41.1 \\
\hline 2. & $\begin{array}{l}\text { Hereditary } \\
\text { Spherocytosis }\end{array}$ & 15.4 & 14.2 & 0 & 0.6 & 29.4 \\
\hline 3. & ITP & 38.4 & 57.4 & 8 & 3.4 & 11.7 \\
\hline 4. & $\begin{array}{l}\text { Sickle Cell } \\
\text { Disease }\end{array}$ & 0 & 0 & 64 & 69.9 & 0 \\
\hline 4. & Others & 0 & 22.8 & 5.4 & 5.2 & 17.4 \\
\hline
\end{tabular}

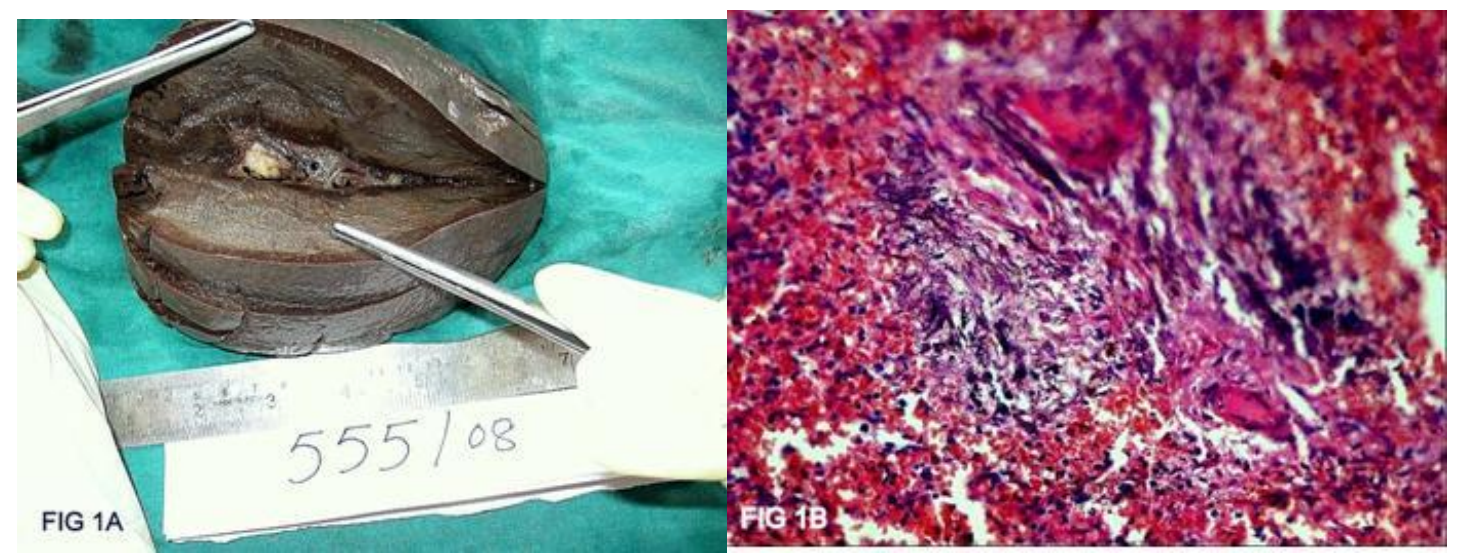

FIGURE 1A FIGURE 1B

FIGURE 1: Spleen in Thalassemia. (A) The cut section of spleen is dark red with prominent red pulp. (B) The histopathology of spleen showing Gamna gandy bodies (Haematoxylin and Eosin, 40x) 


\section{ORIGINAL ARTICLE}

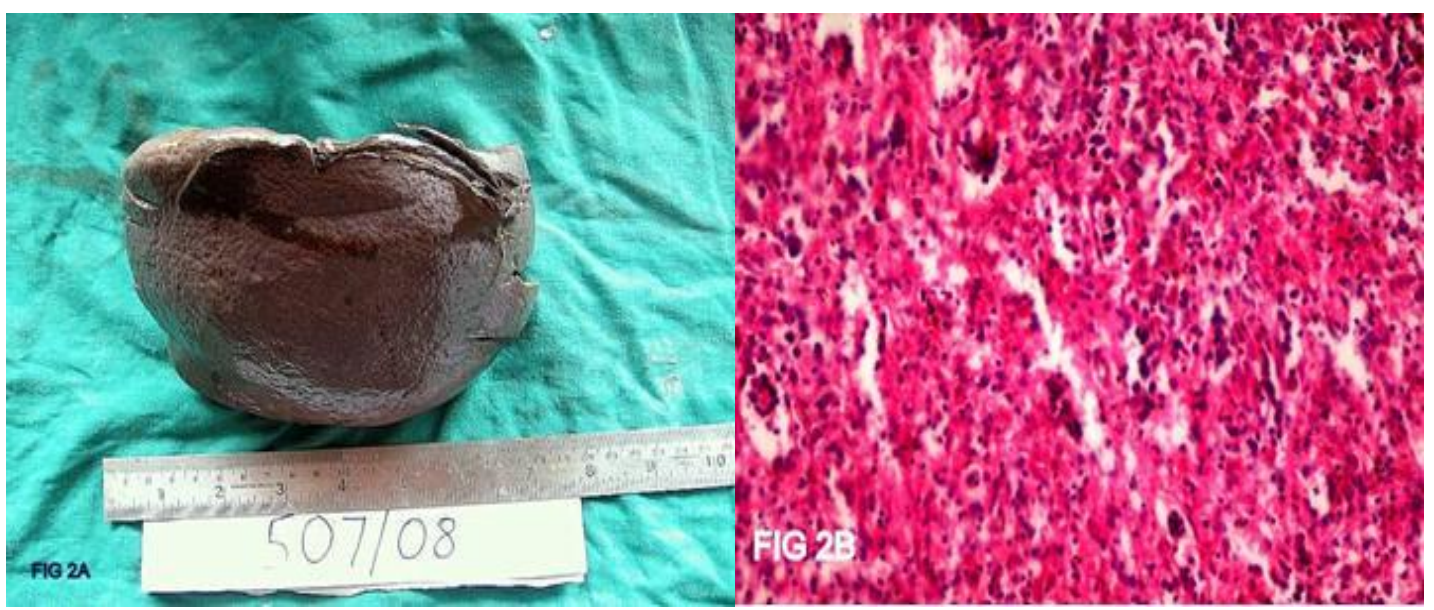

\section{FIGURE 2A FIGURE 2B}

FIGURE 2: Spleen in Hereditary spherocytosis. (A) Gross specimen of spleen showing mild splenomegaly. (B) Histopathology of spleen showing decreased white pulp and sinuses filled with spherocytes (Hematoxylin and Eosin, 40x)

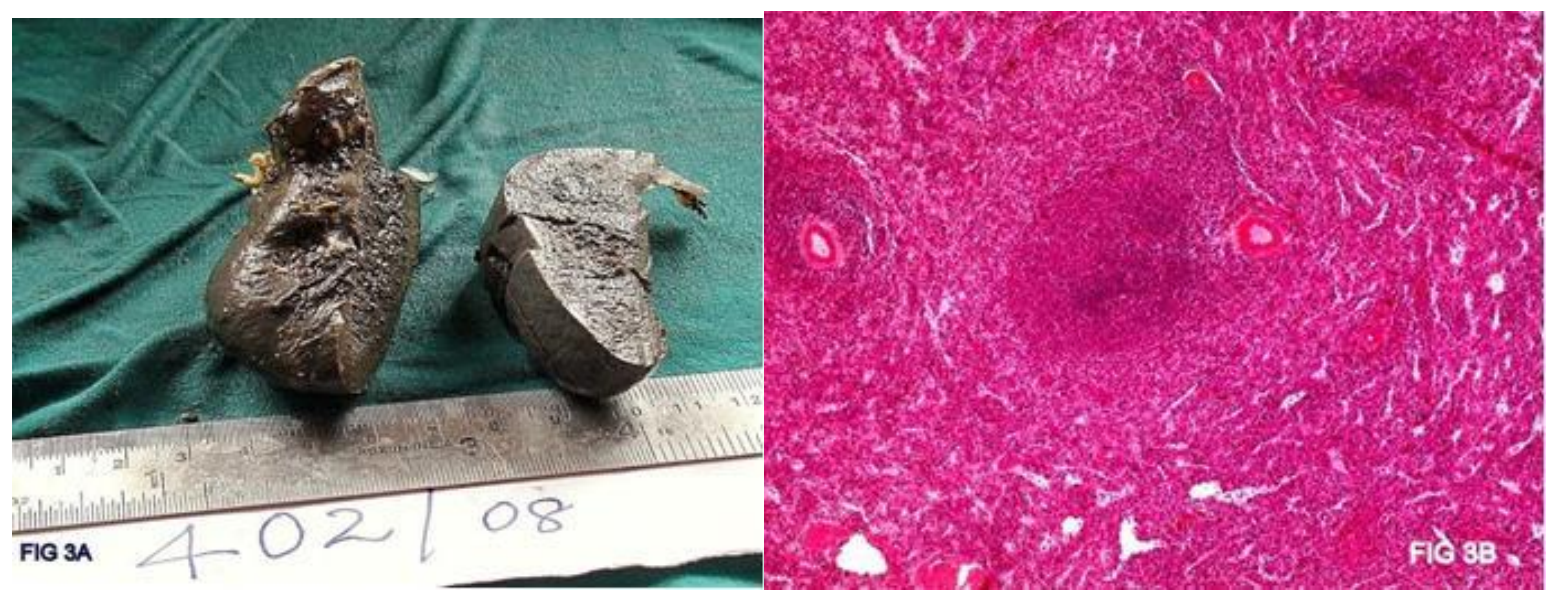

\section{FIGURE 3A FIGURE 3B}

FIGURE 3: Spleen in Idiopathic thrombocytopenic purpura.

(A)Gross specimen of spleen showing mild enlargement and cut section grey tan with congestion. (B) Histopathology of spleen showing reactive follicular hyperplasia in white pulp and prominent red pulp (Hematoxylin and Eosin, 10X) 


\section{ORIGINAL ARTICLE}

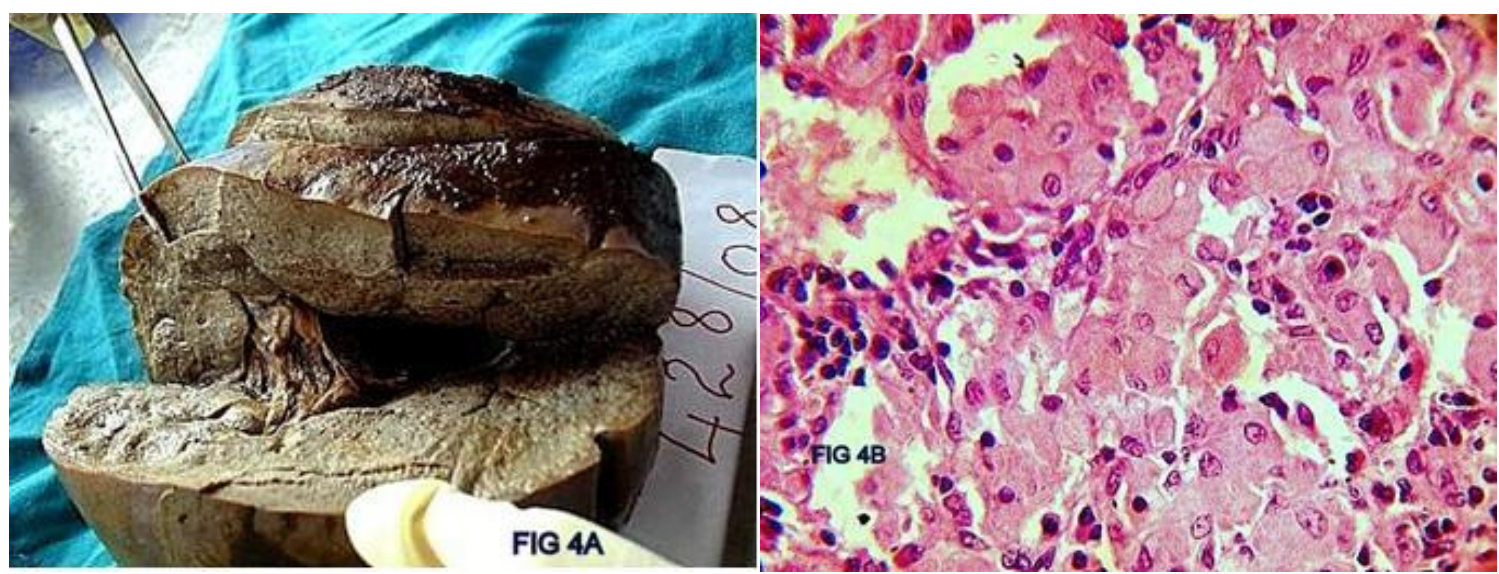

\section{FIGURE 4A FIGURE 4B}

FIGURE 4: Spleen in Gaucher's disease.

(A) The cut section of spleen is pale. (B) Spleen showing nodular \& diffuse infiltrates of Gaucher cells in red pulp (Hematoxylin and Eosin, 40x)

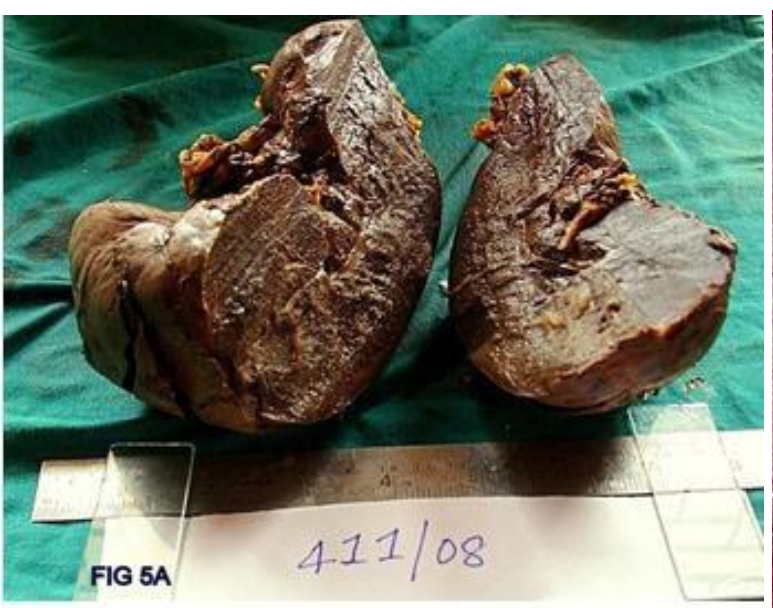

FIGURE 5A FIGURE 5B

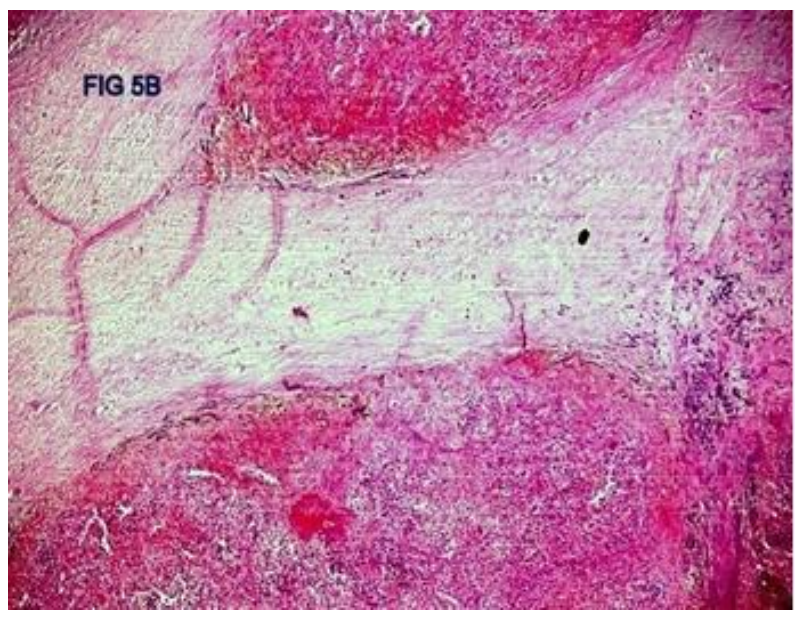

FIGURE 5: Spleen in Kasabach Meritt syndrome. (A) Cut section of spleen is grey tan and congested. (B) Histopathology of spleen showing proliferation of vascular channels of variable size (Hematoxylin and Eosin,10x) 


\section{ORIGINAL ARTICLE}

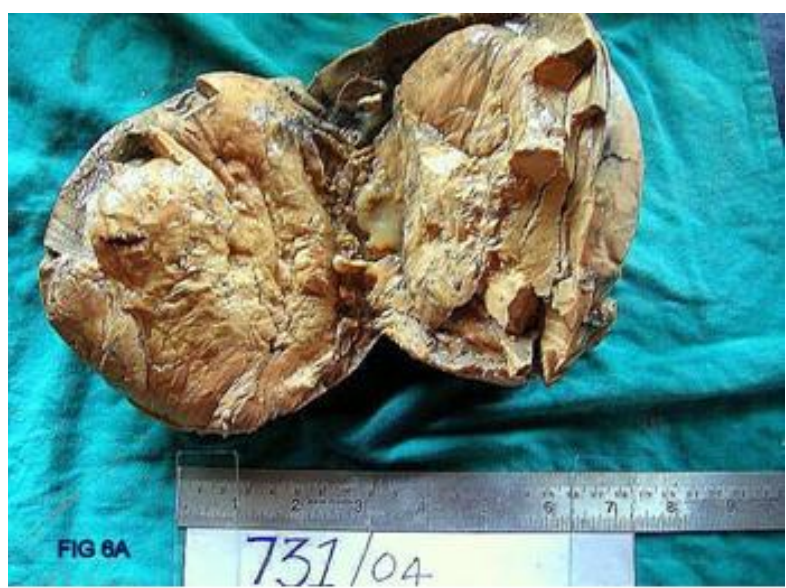

FIGURE 6A FIGURE 6B

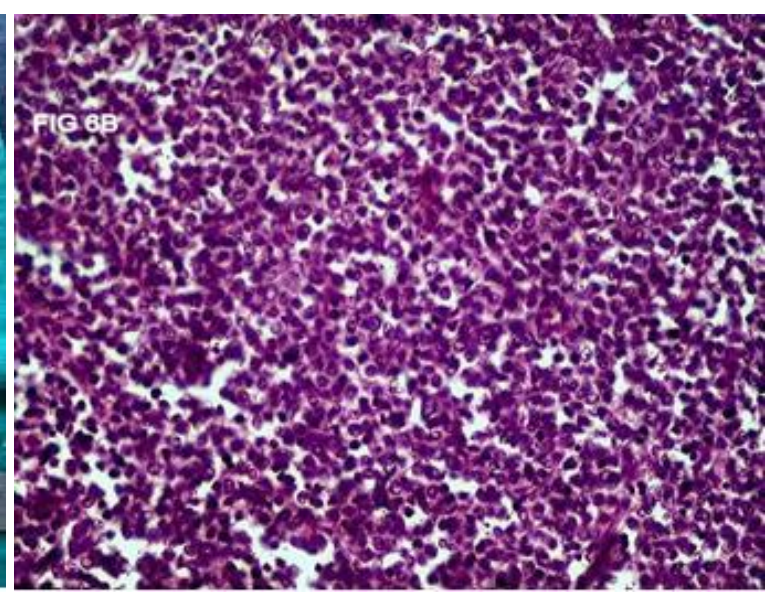

FIGURE 6: Spleen in lymphoma. (A) Cut section of spleen showing a well-defined grey white mass surrounded by normal appearing spleen. (B) Histopathology of spleen showing monotonous infiltrate of atypical lymphocytes with scant cytoplasm, large nuclei and open chromatin (Haematoxylin and Eosin, 40x)
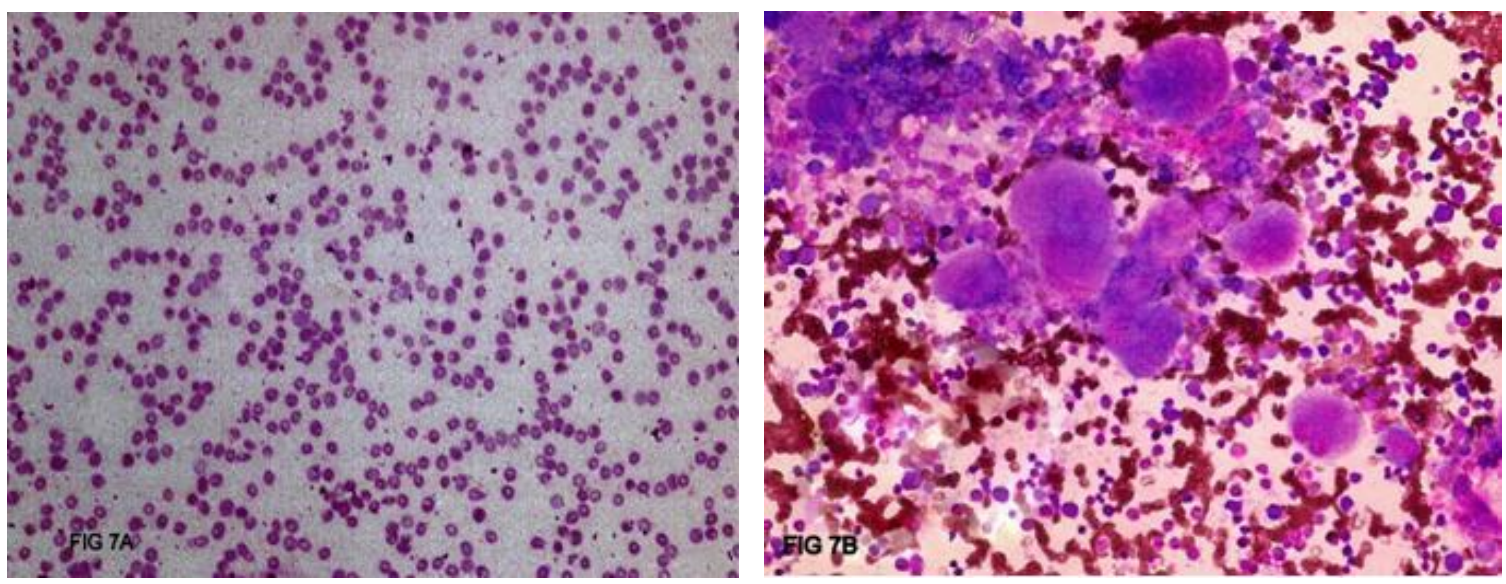

\section{FIGURE 7A FIGURE 7B}

FIGURE 7: (A) Peripheral blood smear of a case of Hereditary spherocytosis. (Leishman's, 40X) (B)Bone marrow smear of a case of Idiopathic Thrombocytopenic Purpura showing increased megakaryocytes. (Leishman's, 40X) 


\section{ORIGINAL ARTICLE}

\section{AUTHORS:}

1. M. Ramani

2. D. Ranganath

3. Kazi Wajid Husain

4. K.Ramesh Reddy

5. Sai Yasaswini

6. Puja Deshmukh

\section{PARTICULARS OF CONTRIBUTORS:}

1. Professor. Department of Pathology, Niloufer Hospital, Hyderabad.

2. Professor, Department of Paediatrics, Niloufer Hospital, Hyderabad.

3. Post Graduate, Department of Pathology, Niloufer Hospital, Hyderabad.

4. Professor and H.O.D, Department Of Paediatric Surgery, Niloufer Hospital, Hyderabad.
5. Undergraduate, Third Year M.B.B.S., Osmania Medical College, Hyderabad.

6. Post graduate, Department of Pathology, Niloufer Hospital, Hyderabad.

\section{NAME ADRRESS EMAIL ID OF THE CORRESPONDING AUTHOR:}

Dr. M. Ramani,

Professor, Department of Pathology,

Niloufer Hospital,

Red hills, Hyderabad,

Andhra Pradesh.

Email-drmramani@sify.com

Date of Submission: 16/06/2013.

Date of Peer Review: 16/06/2013.

Date of Acceptance: 02/07/2013.

Date of Publishing: 11/07/2013 